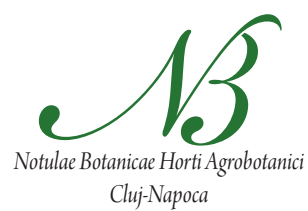

\title{
Field Screening of Sugarcane (Saccharum spp.) Mutant and Commercial Genotypes for Salt Tolerance
}

\author{
Suriyan CHA-UM*, Satjaporn CHANTAWONG ${ }^{2}$, Chareerat MONGKOLSIRIWATANA ${ }^{3}$ \\ Muhammad ASHRAF", Chalermpol KIRDMANEE' \\ ${ }^{1}$ National Center for Genetic Engineering and Biotechnology (BIOTEC), National Science and Technology \\ Development Agency (NSTDA), 113 Thailand Science Park, Paholyothin Road, Khlong Nuang, Khlong \\ Luang, Pathumthani 12120 Thailand; suriyanc@biotec.or.th ("correspondingauthor) \\ ${ }^{2}$ Division of Mitr Phol Research and Development, Mitr Phol Co. Ltd, Phukhew, Chaiyaphum 36110 Thailand \\ ${ }^{3}$ Kasetsart University, Faculty of Liberal Arts and Science, Division of Genetics, Kampangsan Campus, Nakhon Pathom 73140 Thailand \\ ${ }^{4}$ University of Agriculture, Faculty of Science, Department of Botany, Faisalabad 38040 Pakistan
}

\begin{abstract}
Growth and physiological attributes and sugar quality parameters are considered key criteria for screening sugarcane cultivars for salt tolerance. Maximum cane growth and yield were found in a positive check ('K88-92') as well as in cv. '(A3)AE1-18' when subjected to salt affected soil. Percent reduction in $\mathrm{F}_{\mathrm{v}} / \mathrm{F}_{\mathrm{m}}$, quantum efficiency of PSII $\left(\Phi_{\text {PSII }}\right)$ and water use efficiency (WUE) due to salt stress was considerably low in 'K88-92', '(A3)AE1-18' and 'KK3' which was associated with very low salt-induced reduction in net photosynthetic rate and growth characters such as shoot length, number of internodes, and internodal length as well as yield traits. In addition, brix, polarlization, fiber, purity and commercial cane sugar (CCS) in '(A18)AE2-15' and '(A3)AE1-18' were well maintained under saline stress. By subjecting the data for various physiological, growth, yield and sugar quality parameters to the Ward's cluster analysis 'K88-92' (positive check), '(A3)AE1-18' and 'KK3' were identified as salt tolerant, whereas '(A11)AE1-114' and 'K97-32' as salt sensitive.
\end{abstract}

Keywords: cluster analysis, net photosynthetic rate, sugar qualities, water use efficiency, yield traits

\section{Introduction}

Sugarcane (Saccharum sp.) is one of the key commercial crops of the tropical and subtropical zones of the world. However, its yield is reduced to about $50 \%$ when the crop is grown on salt affected soils (Wiedenfeld, 2008). Plant physiological and biochemical responses in sugarcane grown under salt stress have been well documented. For examples, negative effects of saline stress on a number of sugarcane growth and physiological characteristics such as water potential, membrane integrity, nutritional balance, photosynthetic pigments, chlorophyll fluorescence, net photosynthetic rate, growth and yield have been reported (Cha-um and Kirdmanee, 2009; Gomathi and Thandapani, 2004, 2005). However, a great magnitude of intercultivar variation for salt tolerance is reported to occur in the sugarcane germplasm. For example, 'Co 85019', 'Co 94012', 'Co 94008', 'Co 86032', 'Co 92038', 'Co 85004,' 'CPF-213', 'BO91', 'Co 1158', 'CoSe 92423', 'CP-4333', 'S-86-US-699', 'CP66-346' and 'H69-8235' (commercial cultivars and breeding lines) have been categorized as salt tolerant and 'CP-71-3002', 'H65-7052', 'HSF-240', 'L116,' 'Si 940-50', 'Co 85036', 'Co 97010', 'Co 95007', ‘Co 97009' and 'Co 95016' as salt sensitive based on a variety of phenotypic indices (Gandonou et al., 2011; Goma- thi and Thandapani, 2004; Plaut et al., 2000). However, most of the screening studies have been carried out under laboratory or greenhouse conditions. Thus, it is not sure whether degree of salt tolerance of different cultivars observed under controlled or semi-controlled conditions would be maintained under natural field conditions as the latter growth habitat is embraced with a variety of atmospheric and edaphic factors which in combination may enhance the adverse effects of a single stress. Thus, the principal aim of the present investigation was to classify some elite sugarcane genotypes in terms of their tolerance to salt stress imposed by a natural salt affected field, using some key physiological, growth, yield and quality attributes.

\section{Materials and methods}

\section{Plant materials and salt affected treatment}

Six mutant cultivars of sugarcane, '(A3)AE1-17', '(A9) AE1-103', '(A11)AE1-114', '(A13)AE1-126', '(A18) AE2-15' and 'D14' derived from $\gamma$-irradiation and ethyl methane sulfonate (EMS), and 8 commercial cultivars, i.e., 'LK92-11' (wild type), 'K95-84', 'K93-219', 'K84200', 'K97-32', 'Mitr Phol 3', 'KK3' including a positive check ('K88-92') were propagated in MS (Murashige and Skoog, 1962) supplemented with $8.88 \mu \mathrm{M}$ benzyl ad- 
enine (BA), 3\% sucrose and $0.25 \%$ Phytagel" for 6 weeks. Single shoots were excised and roots induced on the MS medium supplemented with $2.46 \mu \mathrm{M}$ indole butyric acid (IBA) for 2 weeks. Plantlets were cultured in vitro under $25 \pm 2^{\circ} \mathrm{C}$ ambient temperature, $60 \pm 5 \%$ relative humidity (RH), and $60 \pm 5 \mu \mathrm{mol} \mathrm{m} \mathrm{s}^{-1}$ photosynthetic photon flux density (PPFD) provided by fluorescent lamps with a $16 \mathrm{~h}$ $\mathrm{d}^{-1}$ photoperiod. Then, the sugarcane plantlets were transferred to MS sugar-free liquid medium using vermiculite as supporting material. The number of air exchanges in the plastic chamber was adjusted to $5.13 \mu \mathrm{mol} \mathrm{CO} \mathrm{h}^{-1}$ by punching 32 holes on sideward of the plastic chamber $(\varnothing$ $1 \mathrm{~cm})$ and covering the holes with microporous filters $(0.2$ $\mu \mathrm{m}$ of pore size). For acclimatization, the plantlets were subsequently cultured in a plant growth incubator under $25 \pm 2^{\circ} \mathrm{C}$ ambient temperature, $60 \pm 5 \% \mathrm{RH}$, and $120 \pm 5$ $\mu \mathrm{mol} \mathrm{m} \mathrm{m}^{-2} \mathrm{~s}^{-1}$ PPFD provided by fluorescent lamps with a $16 \mathrm{~h} \mathrm{~d}^{-1}$ photoperiod and $\mathrm{CO}_{2}$ enrichment at $1,000 \pm 100$ $\mu \mathrm{mol} \mathrm{mol}{ }^{-1}$ (Cha-um et al., 2003). Plantlets of 14 sugarcane cultivars were directly transferred to plastic bags containing clay soil $\left(\mathrm{EC}=2.687 \mathrm{dS} \mathrm{m^{-1 }} ; \mathrm{pH}=5.5\right.$; organic matter $=10.36 \%$; total nitrogen $=0.17 \%$; total phosphorus $=$ $0.07 \%$; total potassium $=1.19 \%)$ in $50 \%$ light intensity in a greenhouse for 1 month. Irrigation was applied as water spray. The acclimatized plants were directly transplanted to a field $(30 \mathrm{~cm}$ plant to plant and $150 \mathrm{~cm}$ row to row distance) at two sites including clay soil (control) and salt affected soil (Tab. 1) at Chaiyaphum province, Northeast of Thailand (Latitude $16^{\circ} 35^{\circ} \mathrm{N}$ and Longitude $101^{\circ}$ $\left.55^{\prime} \mathrm{E}\right)$ for 10 months. Chemical fertilizer (16:16:16; nitrogen: phosphorus: potassium) was applied three times, i.e., February, May and August at $0.0156 \mathrm{~kg} \mathrm{~m}^{-2}$ prior to stalk harvesting in November 2011. Data for plant height, stalk weight, number of stalks per plot, and total stalk weight per plot of sugarcane cultivars were recorded. Photosynthetic abilities, water use efficiency, growth characters, yield attributes, and sugar qualities were measured at the harvesting stage.

\section{Data collection}

Chlorophyll fluorescence parameters such as maximum quantum yield of PSII ( $\left.\mathrm{F}_{\mathrm{v}} / \mathrm{F}_{\mathrm{m}}\right)$, photon yield of PSII, $\left(\Phi_{\mathrm{PSII}}\right)$, photochemical quenching ( $\left.\mathrm{qP}\right)$, and non-photochemical quenching (NPQ) from the youngest fully grown leaf (adaxial surface) from each plant were appraised using a fluorescence meter (FMS2, Hansatech Instrument Ltd., Norfolk, UK) following Loggini et al. (1999). Initial $\left(\mathrm{F}_{0}\right)$ and maximum $\left(\mathrm{F}_{\mathrm{m}}\right)$ fluorescence were measured on a leaf adapted to dark conditions for $30 \mathrm{~min}$. The variable fluorescence yield $\left(\mathrm{F}_{\mathrm{v}}\right)$ was calculated using an equation $\left(\mathrm{F}_{\mathrm{m}}-\right.$ $F_{0}$ ) following Maxwell and Johnson (2000).

Net photosynthetic rate $\left(\mathrm{P} ; \mu \mathrm{mol} \mathrm{m}{ }^{-2} \mathrm{~s}^{-1}\right)$, transpiration rate $\left(\mathrm{E} ; \mathrm{mmol} \mathrm{H}_{2} \mathrm{O} \mathrm{m}^{-2} \mathrm{~s}^{-1}\right)$ and water use efficiency (WUE; $\mu \mathrm{mol} \mathrm{CO} \mathrm{mmol}^{-1} \mathrm{H}_{2} \mathrm{O}$ ) were measured using a Portable Photosynthesis System (Model LI 6400, LI$\mathrm{COR}^{\circledR}$ Inc, Lincoln, Nebraska, USA) with an Infra-red Gas Analyser following Cha-um et al. (2007). Photosynthetic WUE was calculated using the equation: WUE = $\mathrm{P} / \mathrm{E}$.

Shoot height, number of internodes, intermodal length, single stalk weight, and stalk yield were measured at the harvesting stage (10 months after planting). Brix percentage was measured using a hand-held refractrometer (model H-50, ATAGO, Tokyo, Japan). Polarization percentage and fiber percentage were also assayed. Purity percentage was calculated according to equation: Purity $(\%)=[$ Sucrose percentage $/$ Brix percentage $] \times 100$. In addition, commercial cane sugar (CCS) was calculated following the equation: CCS $(\%)=[1.05 \times$ Sucrose percentage $]-[0.292 \times$ Brix percentage $]$ (Meade and Chen, 1977).

\section{Experiment design and statistical analysis}

The experiment was arranged as $14 \times 2$ factorials in a Completely Randomized Block Design (CRBD) with eight replicates $(n=8)$. Significant differences among the mean values were worked out using the Duncan's New DMRT and analyzed with the SPSS software. Data for all variables were subjected to the Ward's method of Hierarchical cluster analysis in SPSS software to classify the cultivars into salt tolerant and salt sensitive categories.

\section{Results and discussion}

\section{Growth performances and yield traits}

Almost all growth attributes measured in the sugarcane cultivars examined in the present investigation were severely affected by salt stress. There was a marked reduction shoot length in all cultivars, but the cultivars differed significantly in this attribute. Salt-induced reduction in shoot length was significantly lower in the positive check 'K8892 ' (4.90\% reduction) than that in the other cultivars, e.g., $14.55 \%$ in 'K95-84' and 41.41\% in '(A11)AE1-114' (Tab. 2 and Fig. 1A). The cultivars also differed significantly for Tab. 1. Soil electrical conductivity $\left(\mathrm{EC}_{\mathrm{e}}\right)$, $\mathrm{pH}$, organic matter $(\mathrm{OM})$, available phosphorus $(\mathrm{P})$, potassium $(\mathrm{K})$, sodium $(\mathrm{Na})$ and chloride $(\mathrm{Cl})$ in the non-saline (control) and salt affected soils at two depths, $0-30 \mathrm{~cm}$ and $30-60 \mathrm{~cm}$

\begin{tabular}{cccccccccc}
\hline Site & $\begin{array}{c}\text { Depth } \\
(\mathrm{cm})\end{array}$ & $\begin{array}{c}\mathrm{EC}_{\mathrm{e}} \\
(\mathrm{dS} \mathrm{m})^{-1}\end{array}$ & $\mathrm{pH}$ & $\begin{array}{c}\mathrm{OM} \\
(\%)\end{array}$ & $\begin{array}{c}\mathrm{P} \\
(\mathrm{ppm})\end{array}$ & $\begin{array}{c}\mathrm{K} \\
(\mathrm{ppm})\end{array}$ & $\begin{array}{c}\mathrm{Na} \\
(\mathrm{ppm})\end{array}$ & $\begin{array}{c}\mathrm{Cl} \\
(\mathrm{ppm})\end{array}$ \\
\hline \multirow{2}{*}{ Control } & $0-30$ & 9.37 & 8.07 & 3.05 & 1884 & 279 & 594 & 778 \\
\hline \multirow{2}{*}{ Salt affected soil } & $30-60$ & 6.18 & 8.23 & 1.14 & 504 & 167 & 530 & 725 \\
& $0-30$ & 37.43 & 6.27 & 0.97 & 460 & 116 & 1348 & 4134 \\
& $30-60$ & 25.20 & 5.99 & 1.03 & 312 & 98 & 1061 & 3221 \\
\hline
\end{tabular}


288

number of internodes under saline stress, e.g. number of internodes reduced to $1.19 \%$ in ' $\mathrm{K} 95-84$ ' and $24.53 \%$ in '(A18)AE2-15' under saline regime (Tab. 2). Internodal length in the salt stressed plants of all cultivars decreased significantly when compared to that in controlled plants varying from $29.41 \%$ reduction in '(A11)AE1-114' to $57.97 \%$ in 'K84-200' (Tab. 2 and Fig. 1B). Single stalk weight in each cultivar decreased significantly due to salt stress, however, there had been considerable variation for salt tolerance in the sugarcane germplasm examined in the present study in terms of single stalk weight (Tab. 2 and Fig. 1C). Yield of sugarcane per sprout in salt stressed plants of all cultivars decreased significantly varying from $22.62 \%$ reduction in 'K95-84' to 75.64\% in 'K97-32' (Tab. 2 and Fig. 1D). Growth parameters are simple, rapid and sensitive method to assay when sugarcane exposed to salt stress. For example, shoot height parameter of sugarcane pot culture was reduced for $8.8 \%$ in salt stressed 'CoS 03261' (8

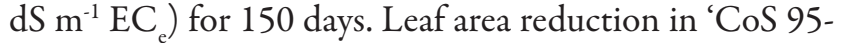
$255^{\prime}$ and 'CoSe 96436 ' was $5.9 \%$ and $8.6 \%$ respectively. In addition, the lowest reduction percentage of dry matter in
'CoS 07250 ' was identified as salt tolerant variety (Saxena et al., 2010). From this it is evident that only one parameter may not be suitable to classify sugarcane cultivars/ lines with regard to degree of salt tolerance. For example, stalk girth, internodal length, and yield of salt tolerant sugarcane cultivars ' $\mathrm{CP} 43-33$ ' and ' $\mathrm{CPF}-213$ ' were higher than those in salt susceptible cv. 'L116' when subjected to varying levels of saline stress for 280 days (Akhtar $e t$ al., 2001). In the same study, reduction in stalk yield and brix percentage in salt tolerant $\mathrm{cv}$. 'CP43-33' was reported to be significantly lower ( $1.88 \%$ and $20.9 \%$ reduction) than that in salt sensitive 'CP-71-3002' (75.30\% and 38.75\%) under $120 \mathrm{mM} \mathrm{NaCl}$. Thus, variation in salt tolerance in sugarcane germplasm in terms of different growth parameters exists and is variable to a great extent depending on the type of cultivars.

\section{Alteration in physiological characteristics}

Maximum quantum yield of PSII $\left(\mathrm{F}_{\mathrm{y}} / \mathrm{F}_{\mathrm{m}}\right)$ in the salt stressed plants of all sugarcane cultivars decreased significantly except in the positive check ('K88-92') and '(A3)

Tab. 2. Shoot length, number of internodes, internodal length, single stalk weight and stalk yield traits in 14 sugarcane genotypes grown under non-saline (control) and salt-affected soils for 10 months

\begin{tabular}{|c|c|c|c|c|c|c|}
\hline Genotypes & Soil & $\begin{array}{c}\text { Shoot length } \\
(\mathrm{cm})\end{array}$ & $\begin{array}{l}\text { Number of } \\
\text { internodes }\end{array}$ & $\begin{array}{c}\text { Internodal length } \\
(\mathrm{cm})\end{array}$ & $\begin{array}{c}\text { Single stalk weight } \\
\left(\mathrm{kg} \mathrm{cane}^{-1}\right)\end{array}$ & $\begin{array}{c}\text { Stalk yield } \\
\left(\text { kg sprout }^{-1}\right)\end{array}$ \\
\hline \multirow{2}{*}{ 'LK92-11' } & Control & $228.3 \mathrm{ab}$ & $23.0 \mathrm{a}$ & $9.85 b$ & $1.75 b c$ & $24.23 \mathrm{~d}$ \\
\hline & salt-affected & 186.5ghi & $16.0 \mathrm{bc}$ & $7.63 c$ & $1.30 \mathrm{~d}$ & $16.71 \mathrm{fg}$ \\
\hline \multirow{2}{*}{ 'K95-84' } & control & $226.8 \mathrm{abc}$ & $21.0 \mathrm{a}$ & $10.08 \mathrm{~b}$ & $2.15 \mathrm{ab}$ & $33.68 \mathrm{ab}$ \\
\hline & salt-affected & $193.8 \mathrm{efg}$ & $20.8 \mathrm{ab}$ & $6.40 \mathrm{~d}$ & $1.85 \mathrm{~b}$ & $26.06 \mathrm{~cd}$ \\
\hline \multirow{2}{*}{ 'K93-219' } & control & $169.3 \mathrm{ijk}$ & $17.0 \mathrm{~b}$ & $15.69 a$ & $1.05 \mathrm{e}$ & 13.26ghi \\
\hline & salt-affected & $125.0 \mathrm{o}$ & $9.5 \mathrm{~d}$ & $9.50 \mathrm{~b}$ & $0.85 f$ & $10.60 \mathrm{ij}$ \\
\hline \multirow{2}{*}{ 'D14' } & control & 213.5bcd & $24.8 \mathrm{a}$ & $10.62 b$ & $2.05 b$ & $36.37 \mathrm{a}$ \\
\hline & salt-affected & $165.3 \mathrm{jkl}$ & $14.8 \mathrm{c}$ & $10.11 \mathrm{~b}$ & $1.75 \mathrm{bc}$ & $24.51 d$ \\
\hline \multirow{2}{*}{ 'K84-200’ } & control & $161.8 \mathrm{jkl}$ & $16.0 \mathrm{bc}$ & $14.75 \mathrm{a}$ & $0.93 \mathrm{f}$ & $12.90 \mathrm{fgh}$ \\
\hline & salt-affected & $131.0 \mathrm{o}$ & $10.0 \mathrm{~d}$ & $6.20 \mathrm{~d}$ & $0.55 \mathrm{~g}$ & $8.08 \mathrm{i}$ \\
\hline \multirow{2}{*}{ 'A9' } & control & 171.0hij & $25.8 \mathrm{a}$ & 13.18ab & $1.35 \mathrm{~d}$ & $14.28 \mathrm{fgh}$ \\
\hline & salt-affected & $142.0 \mathrm{mno}$ & $13.3 \mathrm{~cd}$ & $10.16 \mathrm{~b}$ & $0.90 \mathrm{f}$ & $8.80 \mathrm{i}$ \\
\hline \multirow{2}{*}{ 'K97-32' } & control & $224.3 \mathrm{abc}$ & $24.0 \mathrm{a}$ & $10.56 \mathrm{~b}$ & $2.50 \mathrm{a}$ & $36.62 \mathrm{a}$ \\
\hline & salt-affected & 138.0no & $15.0 \mathrm{bc}$ & $7.31 \mathrm{c}$ & $0.90 \mathrm{f}$ & $8.92 \mathrm{i}$ \\
\hline \multirow{2}{*}{ 'A18' } & control & 179.3ghi & $13.3 \mathrm{~cd}$ & $11.53 b$ & $1.05 \mathrm{e}$ & 11.83ghi \\
\hline & salt-affected & 132.30 & $10.0 \mathrm{~d}$ & $7.25 c$ & $0.95 f$ & $7.96 \mathrm{i}$ \\
\hline \multirow{2}{*}{ 'A13' } & control & $231.5 \mathrm{a}$ & $25.3 \mathrm{a}$ & $8.56 \mathrm{bc}$ & $2.10 \mathrm{ab}$ & $26.80 \mathrm{~cd}$ \\
\hline & salt-affected & $193.3 \mathrm{efg}$ & $20.0 \mathrm{ab}$ & $6.58 \mathrm{~d}$ & $1.70 \mathrm{bc}$ & $18.18 \mathrm{ef}$ \\
\hline \multirow{2}{*}{ 'Mitr Phol 3' } & control & 206.0def & $18.3 b$ & $13.13 \mathrm{ab}$ & $1.80 \mathrm{bc}$ & $25.04 \mathrm{~cd}$ \\
\hline & salt-affected & $154.8 \mathrm{klm}$ & $11.8 \mathrm{~cd}$ & $6.75 \mathrm{~d}$ & $1.05 \mathrm{e}$ & $17.85 \mathrm{ef}$ \\
\hline \multirow{2}{*}{ 'A11' } & control & $225.3 \mathrm{abc}$ & $17.5 \mathrm{~b}$ & $10.93 b$ & $1.90 \mathrm{~b}$ & $23.71 d$ \\
\hline & salt-affected & 131.80 & $9.8 \mathrm{~d}$ & $7.71 \mathrm{c}$ & $0.70 \mathrm{f}$ & $7.72 \mathrm{i}$ \\
\hline \multirow{2}{*}{ 'K88-92' } & control & $214.3 \mathrm{bcd}$ & $20.3 \mathrm{ab}$ & $9.13 b$ & $2.08 b$ & $29.85 \mathrm{bc}$ \\
\hline & salt-affected & 203.8def & $16.8 \mathrm{~b}$ & $6.35 \mathrm{~d}$ & $1.80 \mathrm{bc}$ & $22.54 \mathrm{~d}$ \\
\hline \multirow{2}{*}{ 'KK3' } & control & 184.5fgh & $15.5 b c$ & $13.89 \mathrm{ab}$ & $1.90 \mathrm{~b}$ & $23.30 \mathrm{~d}$ \\
\hline & salt-affected & $147.0 \mathrm{mno}$ & $10.5 \mathrm{~d}$ & $10.29 \mathrm{~b}$ & $0.90 \mathrm{f}$ & $16.42 \mathrm{fg}$ \\
\hline \multirow{2}{*}{ 'A3' } & control & $205.3 \mathrm{def}$ & $18.7 \mathrm{~b}$ & $11.96 \mathrm{~b}$ & $1.40 \mathrm{~cd}$ & $17.67 \mathrm{ef}$ \\
\hline & salt-affected & 173.8ghi & $12.8 \mathrm{c}$ & $8.63 \mathrm{bc}$ & $1.15 \mathrm{e}$ & 12.94ghi \\
\hline
\end{tabular}

Different letters in each column show significant difference at $p \leq 0.01$ by the Duncan's New Multiple Range Test (DMRT) 

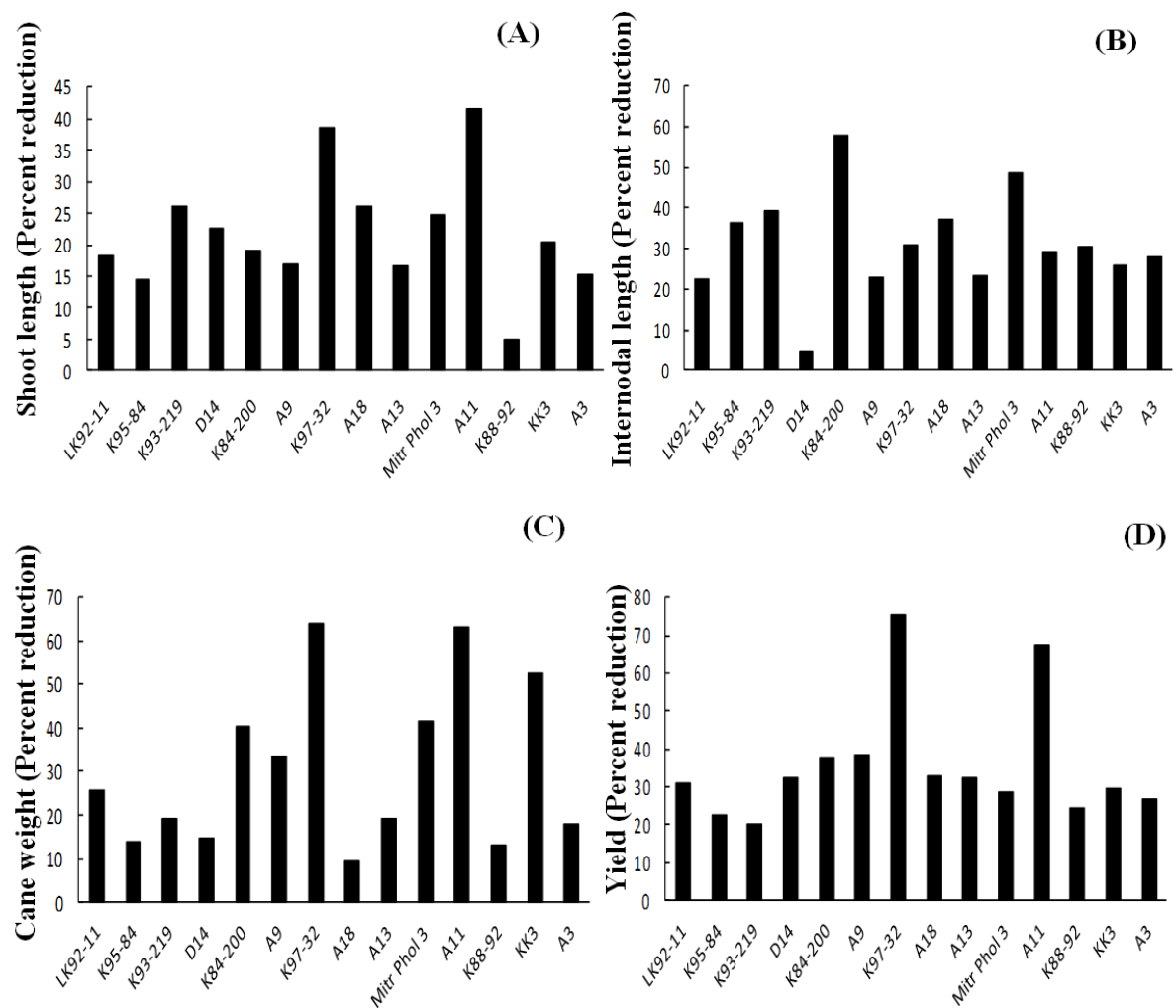

(C)

(D)

Sugarcane genotypes

Fig. 1. Percent reduction in shoot length(A), internodal length (B), cane weight (C), and yield (D) in 14 sugarcane genotypes grown under non-saline (control) and salt-affected soils for 10 months

(A)

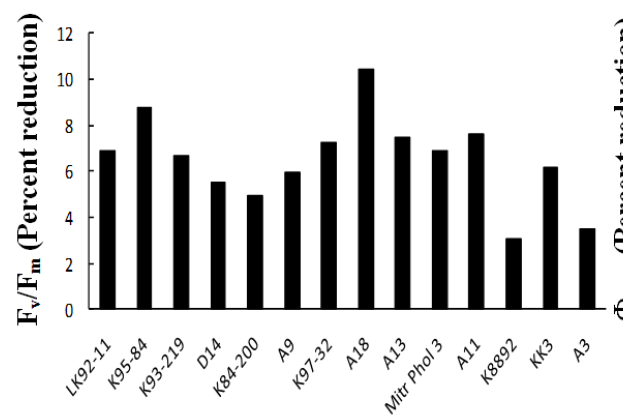

(C)

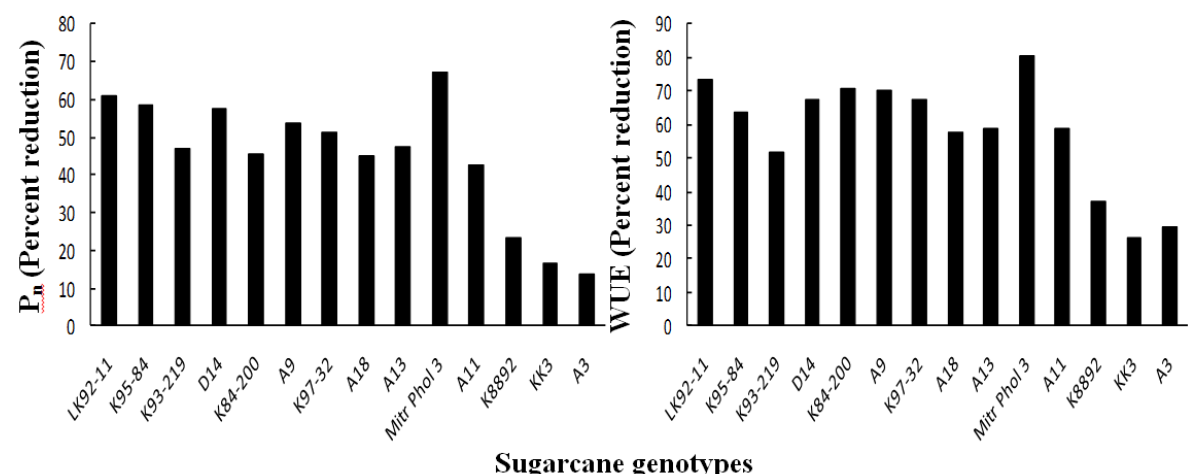

Fig. 2. Percent reduction in $F_{v} / F_{m}(A), \Phi_{\text {PSII }}(B), P_{n}(C)$, and WUE (D) in 14 sugarcane genotypes grown under non-saline (control) and salt-affected soils for 10 months 
290

Tab. 3. Maximum quantum yield of PSII $\left(\mathrm{F}_{\mathrm{v}} / \mathrm{F}_{\mathrm{m}}\right)$, photon yield of PSII $\left(\Phi_{\text {PSII }}\right)$, net photosynthetic rate $\left(\mathrm{P}_{\mathrm{n}}\right)$ and water use efficiency (WUE) in 14 sugarcane genotypes grown under non-saline (control) and salt-affected soils for 10 months

\begin{tabular}{|c|c|c|c|c|c|}
\hline Genotypes & Soil & $\mathrm{F}_{\mathrm{v}} / \mathrm{F}_{\mathrm{m}}$ & $\Phi_{\text {PSII }}$ & $\begin{array}{c}\mathrm{P}_{\mathrm{n}} \\
\left(\mu \mathrm{mol} \mathrm{m}^{-2} \mathrm{~s}^{-1}\right)\end{array}$ & $\begin{array}{c}\text { WUE } \\
\left(\mu \mathrm{mol} \mathrm{CO}{ }_{2} \mathrm{mmol}^{-1} \mathrm{H}_{2} \mathrm{O}\right)\end{array}$ \\
\hline \multirow{2}{*}{ 'LK92-11' } & control & $0.893 \mathrm{ab}$ & $0.829 a$ & $74.1 \mathrm{a}$ & $123.5 \mathrm{cde}$ \\
\hline & salt-affected & $0.832 \mathrm{efg}$ & $0.732 \mathrm{bc}$ & 29.0hi & $32.6 \mathrm{kl}$ \\
\hline \multirow{2}{*}{ 'K95-84' } & control & $0.891 \mathrm{ab}$ & $0.806 \mathrm{a}$ & $74.7 \mathrm{a}$ & 107.4fgh \\
\hline & salt-affected & $0.813 \mathrm{fg}$ & $0.721 b c$ & $31.2 \mathrm{gh}$ & $39.3 \mathrm{jkl}$ \\
\hline \multirow{2}{*}{ 'K93-219' } & control & $0.899 \mathrm{ab}$ & $0.823 a$ & $74.2 \mathrm{a}$ & 108.7fgh \\
\hline & salt-affected & $0.839 \mathrm{def}$ & $0.741 b c$ & $39.5 \mathrm{de}$ & $52.8 \mathrm{j}$ \\
\hline \multirow{2}{*}{ 'D14' } & control & $0.905 \mathrm{a}$ & $0.808 \mathrm{a}$ & $71.8 \mathrm{a}$ & 113.0fgh \\
\hline & salt-affected & $0.855 \mathrm{cde}$ & $0.726 b c$ & $30.7 \mathrm{gh}$ & $36.6 \mathrm{jkl}$ \\
\hline \multirow{2}{*}{ 'K84-200' } & control & $0.882 \mathrm{abc}$ & $0.814 a$ & $75.0 \mathrm{a}$ & $145.8 \mathrm{a}$ \\
\hline & salt-affected & $0.839 \mathrm{def}$ & $0.716 \mathrm{bcd}$ & $41.0 \mathrm{~d}$ & $42.6 \mathrm{jkl}$ \\
\hline \multirow{2}{*}{ 'A9' } & control & $0.891 \mathrm{ab}$ & $0.816 \mathrm{a}$ & $74.6 a$ & $135.8 \mathrm{abc}$ \\
\hline & salt-affected & $0.838 \mathrm{def}$ & $0.720 b c$ & $34.6 \mathrm{fg}$ & $40.4 \mathrm{jkl}$ \\
\hline \multirow{2}{*}{ 'K97-32' } & control & $0.905 a$ & $0.840 \mathrm{a}$ & $74.0 \mathrm{a}$ & $130.6 \mathrm{abc}$ \\
\hline & salt-affected & $0.839 \mathrm{def}$ & $0.736 b c$ & $36.0 \mathrm{ef}$ & $42.9 \mathrm{jkl}$ \\
\hline \multirow{2}{*}{ 'A18' } & control & $0.896 \mathrm{ab}$ & $0.830 \mathrm{a}$ & $72.1 \mathrm{a}$ & 103.0 gh \\
\hline & salt-affected & $0.802 \mathrm{f}$ & $0.677 \mathrm{~d}$ & $39.7 \mathrm{de}$ & $43.6 \mathrm{jkl}$ \\
\hline \multirow{2}{*}{ 'A13' } & control & $0.893 \mathrm{ab}$ & $0.804 a$ & $75.4 a$ & 116.6efg \\
\hline & salt-affected & $0.826 \mathrm{efg}$ & $0.721 b c$ & $39.6 \mathrm{de}$ & $48.1 \mathrm{jk}$ \\
\hline \multirow{2}{*}{ 'Mitr Phol 3' } & control & $0.897 \mathrm{ab}$ & $0.817 \mathrm{a}$ & $75.0 \mathrm{a}$ & $144.9 \mathrm{a}$ \\
\hline & salt-affected & $0.835 \mathrm{efg}$ & $0.751 \mathrm{~b}$ & $24.6 \mathrm{i}$ & 28.41 \\
\hline \multirow{2}{*}{ 'A11' } & control & $0.897 \mathrm{ab}$ & $0.811 \mathrm{a}$ & $75.4 a$ & $125.9 \mathrm{cde}$ \\
\hline & salt-affected & $0.829 \mathrm{efg}$ & $0.697 \mathrm{~cd}$ & $43.2 \mathrm{~d}$ & $51.9 \mathrm{j}$ \\
\hline \multirow{2}{*}{ 'K88-92' } & control & $0.893 \mathrm{ab}$ & $0.817 \mathrm{a}$ & $71.3 \mathrm{a}$ & $116.9 \mathrm{efg}$ \\
\hline & salt-affected & $0.866 \mathrm{bcd}$ & $0.761 \mathrm{~b}$ & $58.4 \mathrm{c}$ & $73.4 \mathrm{i}$ \\
\hline \multirow{2}{*}{ 'KK3' } & control & $0.903 \mathrm{ab}$ & $0.823 \mathrm{a}$ & $74.9 \mathrm{a}$ & $141.6 \mathrm{ab}$ \\
\hline & salt-affected & $0.847 \mathrm{def}$ & $0.743 b$ & $62.5 \mathrm{~b}$ & $104.8 \mathrm{gh}$ \\
\hline \multirow{2}{*}{ 'A3' } & control & $0.886 a b c$ & $0.823 \mathrm{a}$ & $74.2 \mathrm{a}$ & $138.2 \mathrm{abc}$ \\
\hline & salt-affected & $0.855 \mathrm{cde}$ & $0.746 b$ & $64.0 \mathrm{~b}$ & $97.4 \mathrm{~h}$ \\
\hline
\end{tabular}

Different letters in each column show significant difference at $p \leq 0.01$ by the Duncan's New Multiple Range Test (DMRT)

AE1-17' in which reduction in this trait had been only $3.02 \%$ and $3.50 \%$, respectively. In contrast, percent reduction in $\mathrm{F}_{r} / \mathrm{F}_{\text {in }}$ in the other sugarcane cultivars ranged from $4.95 \%$ in' K84-200') to $10.46 \%$ in '(A18)AE2-15' (Fig. 2A). Photon yield of PSII $\left(\Phi_{\text {PSII }}\right)$, net photosynthetic rate $\left(P_{n}\right)$ and water use efficiency $\left(W U E=P_{n} / E\right)$ in all sugarcane cultivars declined significantly under saline stress (Tab. 3). Leaf $P_{n}$ and WUE were found to be very sensitive parameters in sugarcane cultivars subjected to salt affected soil, especially in salt sensitive cultivars. The $\Phi_{\text {PSII }}$ in the salt stressed sugarcane plants decreased significantly, e.g., 8.04\% reduction in 'Mitr Phol 3', 6.78\% in 'K88-92' (6.78\%), 9.76\% in 'KK3' (9.76\%) and 9.39\% in '(A3)AE1-17' (Fig. 1B). Similarly, percent reduction in $\mathrm{P}_{\mathrm{n}}$ salt stressed plants of 'K88-92', 'KK3' and '(A3)AE1$17^{\mathrm{n}}$ ' was $23.13 \%, 16.53 \%$ and $13.71 \%$, respectively (Fig. 1C). Also, WUE in the salt stressed plants of 'K88-92' (37.20\%), 'KK3' (26.01\%) and '(A3)AE1-17' (29.51\%) was $37.2 \%, 26.01 \%$, and $29.51 \%$, respectively (Fig. 1D). In the present study, $\mathrm{P}_{\mathrm{n}}$ (42.69-67.23\%) and WUE (51.43$80.43 \%)$ in salt sensitive cultivars were also sensitive than $\mathrm{F}_{\mathrm{v}} / \mathrm{F}_{\mathrm{m}}(4.95-10.46 \%)$ and $\Phi_{\mathrm{PSII}}(10.06-18.51 \%)$. In vitro salt tolerant screening, $\mathrm{F}_{\mathrm{v}} / \mathrm{F}_{\mathrm{m}}, \Phi_{\mathrm{PSII}}$, quantum efficiency of PSII (qP) and $\mathrm{P}_{\mathrm{n}}$ in salt stressed plantlets $(200 \mathrm{mM} \mathrm{NaCl})$ were sharply decreased. Only $\Phi_{\mathrm{PSII}}$ and qP in salt stressed 'K88-1' or 'K88-92' cultivar were maintained at $<10 \%$ diminishing (Cha-um et al., 2012). Also, the salt tolerant cultivar, 'K88-92' was applied as positive check in the field trial. The photosynthetic abilities in salt stressed plants have been potentially classified the salt tolerance in sugarcane. For example, diminishing of $\mathrm{F}_{\mathrm{v}} / \mathrm{F}_{\mathrm{m}}$ in salt tolerant genotypes, 'C 92038' (9.28\%) and 'Č o 85004' (6.85\%) of sugarcane in mature and reproductive stage was lower than that in salt sensitive, 'Si 94050' (17.35\%) and 'Co 85036 ' (22.46\%) when subjected to $1 \% \mathrm{NaCl}\left(\mathrm{EC}_{\mathrm{c}} 7 \mathrm{dS}\right.$ $\mathrm{m}^{-1}$ ) (Gomathi et al., 2010; Gomathi and Rakkiyapan, 2011). Vasantha et al. (2010) reported that the $P_{n}$ in 8 sugarcane cultivars declined significantly but to a varying extent when treated with salt stress of EC $8 \mathrm{dS} \mathrm{m}^{-1}$. Percent reduction in $\mathrm{P}_{\text {c }}$ cvs. 'Co 94012' and 'Co 94008' had been $4.57 \%$ and $4.56 \%$, respectively, whereas that in other cultivars had been from $11.57 \%$ in 'Co 86032') to $46.25 \%$ in 'Co 97009' (Vasantha et al., 2010). It has been reported 


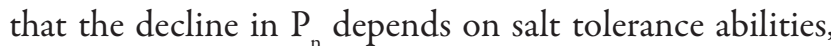
level of salt stress and period of salt treatment.

\section{Quality of sugarcane and cluster analysis}

Brix percentage of five sugarcane cultivars, 'K93-219', 'K84-200', '(A9)AE1-103', 'K97-32' and 'KK3' significantly decreased when plants were subjected to salt affected soil, i.e., varying from $17.49 \%$ in 'K84-200' to $26.58 \%$ in 'KK3', whereas that of other cultivars remained almost unchanged (Tab. 4 and Fig. 3). Polarization, fiber, purity and commercial cane sugar (CCS) percentages in salt stressed plants of all sugarcane cultivars also decreased significantly, especially in '(A13)AE1-126' (34.53\%, 16.26\%, $11.56 \%$ and $38.0 \%$ reduction, respectively), and 'KK3' (36.79\%, 35.12\%, 16.42\% and $41.19 \%$, respectively (Tab. 4 and Fig. 3). In contrast, the reduction in these quality parameters in the positive salt tolerant check 'K88-92' was relatively lower, i.e., $13.57 \%, 10.14 \%, 3.88 \%$ and $14.33 \%$ reduction, respectively. The data for physiological attributes, plant growth, yield potential and quality traits of sugarcane genotypes were subjected to the multivariate cluster analysis, through which it was possible to identify salt tolerant cluster as '(A3)AE1-11' and 'KK3' where in the positive check 'K88-92' was also present (Fig. 4). Also, '(A11)AE1-114' was classified as salt susceptible where in the negative check 'K97-32' was presented. Lingle and Wiegand (1997) have reported that brix, polarization and purity percentage of sugarcane cultivar ' $\mathrm{CP} 70-321$ ' declined depending on soil salinity of a salt affected field (2$10 \mathrm{dS} \mathrm{m}^{-1} \mathrm{EC}_{\mathrm{c}}$ ). Also, brix, sucrose, purity and CCS in salt tolerant cultivars, 'C 92038' and 'Co 85004', have been reported to be maintained better than those in salt susceptible cultivars, 'Si 94050' and 'Co 85036' (Gomathi and Thandapani, 2005). In a previous study, the multivariate cluster analysis (Ward's method) has been found to be very effective in screening some commercial sugarcane cultivars for salt tolerance under controlled conditions (Cha-um et al., 2012). However, in the recent report, changes in physiological and growth characters, yield attributes and quality of sugarcane were evaluated in a salt affected field.

In conclusion, salinity-induced decline in chlorophyll fluorescence, $\mathrm{P}_{\mathrm{n}}$, growth, yield and quality in salt stressed

Tab. 4. Brix percentage, polarization percentage, fiber percentage, purity and commercial cane sugar (CCS) traits in 14 sugarcane genotypes grown under non-saline (control) and salt-affected soils for 10 months

\begin{tabular}{|c|c|c|c|c|c|c|}
\hline Genotypes & Soil & $\begin{array}{l}\text { Brix } \\
(\%)\end{array}$ & $\begin{array}{c}\text { Polarization } \\
(\%)\end{array}$ & $\begin{array}{c}\text { Fiber } \\
(\%)\end{array}$ & $\begin{array}{c}\text { Purity } \\
(\%)\end{array}$ & $\begin{array}{c}\text { CCS } \\
(\%)\end{array}$ \\
\hline \multirow{2}{*}{ ‘LK92-11’ } & Control & $21.85 \mathrm{a}$ & $13.21 b c$ & $12.45 \mathrm{~b}$ & $80.86 b c$ & $9.69 \mathrm{bc}$ \\
\hline & salt-affected & $20.30 \mathrm{a}$ & $9.41 \mathrm{~d}$ & $10.39 \mathrm{c}$ & $71.84 \mathrm{c}$ & $6.12 \mathrm{~cd}$ \\
\hline \multirow{2}{*}{ 'K95-84' } & Control & $19.20 \mathrm{ab}$ & $16.70 \mathrm{~b}$ & $14.72 \mathrm{a}$ & $85.89 \mathrm{a}$ & $12.11 \mathrm{a}$ \\
\hline & salt-affected & $16.45 b c$ & $15.25 \mathrm{~b}$ & $11.85 \mathrm{~b}$ & $84.45 a$ & $11.33 \mathrm{ab}$ \\
\hline \multirow{2}{*}{ 'K93-219' } & Control & $18.45 \mathrm{~b}$ & $13.67 \mathrm{bc}$ & $11.96 \mathrm{~b}$ & $80.23 b c$ & $9.87 \mathrm{bc}$ \\
\hline & salt-affected & $14.40 \mathrm{c}$ & $10.87 \mathrm{~cd}$ & $11.26 \mathrm{bc}$ & $74.99 \mathrm{c}$ & $7.38 \mathrm{c}$ \\
\hline \multirow{2}{*}{ 'D14' } & Control & $20.75 a$ & $14.97 \mathrm{bc}$ & $12.69 \mathrm{~b}$ & $83.07 \mathrm{a}$ & $10.91 \mathrm{~b}$ \\
\hline & salt-affected & $17.75 b c$ & $12.06 \mathrm{c}$ & $12.52 \mathrm{~b}$ & $77.49 \mathrm{bc}$ & $8.33 c$ \\
\hline \multirow{2}{*}{ 'K84-200’ } & Control & $19.15 \mathrm{ab}$ & $10.56 \mathrm{~cd}$ & $12.05 \mathrm{~b}$ & $75.31 \mathrm{c}$ & $7.33 c$ \\
\hline & salt-affected & $15.80 \mathrm{c}$ & $8.77 \mathrm{~d}$ & $10.33 \mathrm{c}$ & $70.23 c$ & $5.61 \mathrm{~d}$ \\
\hline \multirow{2}{*}{ 'A9' } & Control & $21.10 \mathrm{a}$ & $15.28 b$ & $12.45 \mathrm{~b}$ & $86.30 \mathrm{a}$ & $11.32 \mathrm{ab}$ \\
\hline & salt-affected & $16.65 b c$ & $12.82 \mathrm{c}$ & $12.03 \mathrm{~b}$ & $84.30 \mathrm{a}$ & $9.59 \mathrm{bc}$ \\
\hline \multirow{2}{*}{ 'K97-32' } & Control & $18.20 \mathrm{~b}$ & $12.76 \mathrm{c}$ & $11.29 b c$ & $81.00 \mathrm{~b}$ & $9.29 b c$ \\
\hline & salt-affected & $13.90 \mathrm{c}$ & $9.84 \mathrm{~d}$ & $11.19 b c$ & $71.65 c$ & $6.47 \mathrm{~cd}$ \\
\hline \multirow{2}{*}{ 'A18' } & Control & $19.00 \mathrm{ab}$ & $13.42 \mathrm{bc}$ & $11.55 b c$ & $81.35 b$ & $9.80 \mathrm{bc}$ \\
\hline & salt-affected & $16.75 b c$ & $12.01 \mathrm{c}$ & $11.13 b c$ & $77.11 b c$ & $8.38 \mathrm{c}$ \\
\hline \multirow{2}{*}{ 'A13' } & Control & $21.10 \mathrm{a}$ & $18.45 \mathrm{a}$ & $14.76 a$ & $89.30 \mathrm{a}$ & $13.71 \mathrm{a}$ \\
\hline & salt-affected & $19.40 \mathrm{ab}$ & $12.08 \mathrm{c}$ & $12.36 \mathrm{~b}$ & $78.98 \mathrm{bc}$ & $8.50 \mathrm{c}$ \\
\hline \multirow{2}{*}{ 'Mitr Phol 3' } & Control & $19.10 \mathrm{ab}$ & $15.55 \mathrm{~b}$ & $10.87 \mathrm{bc}$ & $85.84 a$ & $11.94 \mathrm{a}$ \\
\hline & salt-affected & $16.55 b c$ & $13.37 \mathrm{bc}$ & $10.06 \mathrm{c}$ & $81.34 \mathrm{~b}$ & $9.80 \mathrm{bc}$ \\
\hline \multirow{2}{*}{ 'A11' } & Control & $18.55 b$ & $13.65 \mathrm{bc}$ & $10.62 b c$ & $81.24 b$ & $10.02 \mathrm{~b}$ \\
\hline & salt-affected & $16.60 \mathrm{bc}$ & $10.92 \mathrm{~cd}$ & $10.35 c$ & $75.96 \mathrm{c}$ & $7.64 c$ \\
\hline \multirow{2}{*}{ 'K88-92' } & Control & $16.35 b c$ & $16.88 \mathrm{~b}$ & 13.31ab & $87.74 a$ & $12.63 \mathrm{a}$ \\
\hline & salt-affected & $14.65 \mathrm{c}$ & $14.59 \mathrm{bc}$ & $11.99 \mathrm{~b}$ & $84.34 a$ & $10.82 \mathrm{~b}$ \\
\hline \multirow{2}{*}{ 'KK3' } & Control & $18.25 \mathrm{~b}$ & $14.65 b c$ & $15.86 \mathrm{a}$ & $84.95 a$ & $10.39 \mathrm{~b}$ \\
\hline & salt-affected & $13.40 \mathrm{c}$ & $9.26 \mathrm{~d}$ & $10.29 \mathrm{c}$ & $71.00 \mathrm{c}$ & $6.11 \mathrm{~cd}$ \\
\hline \multirow{2}{*}{ 'A3' } & Control & $22.50 \mathrm{a}$ & $14.51 b c$ & $13.68 \mathrm{ab}$ & $83.67 \mathrm{ab}$ & $10.61 \mathrm{~b}$ \\
\hline & salt-affected & $19.50 \mathrm{ab}$ & $14.01 b c$ & $12.67 \mathrm{~b}$ & $82.87 \mathrm{ab}$ & $10.04 \mathrm{~b}$ \\
\hline
\end{tabular}

Different letters in each column show significant difference at $p \leq 0.01$ by the Duncan's New Multiple Range Test (DMRT) 
(A)

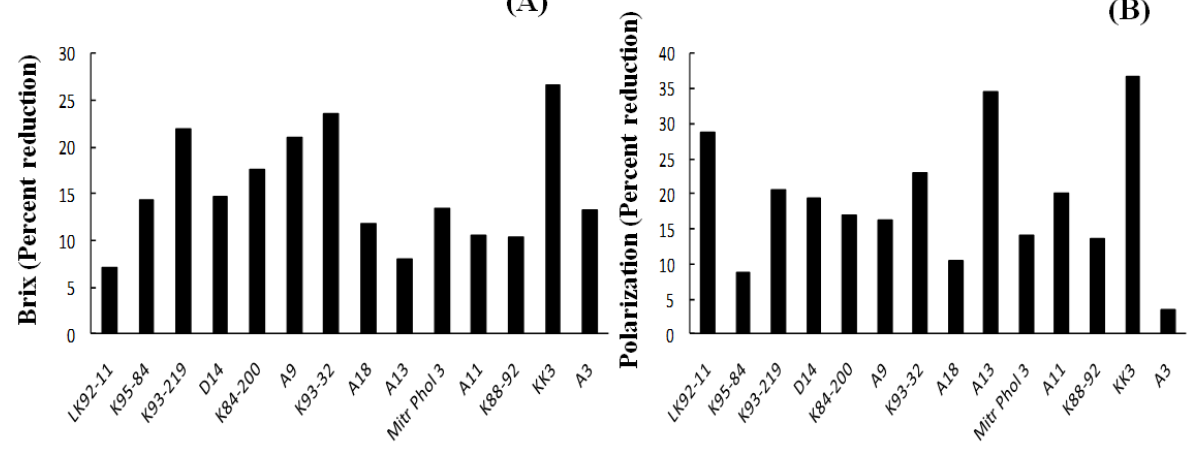

(C)

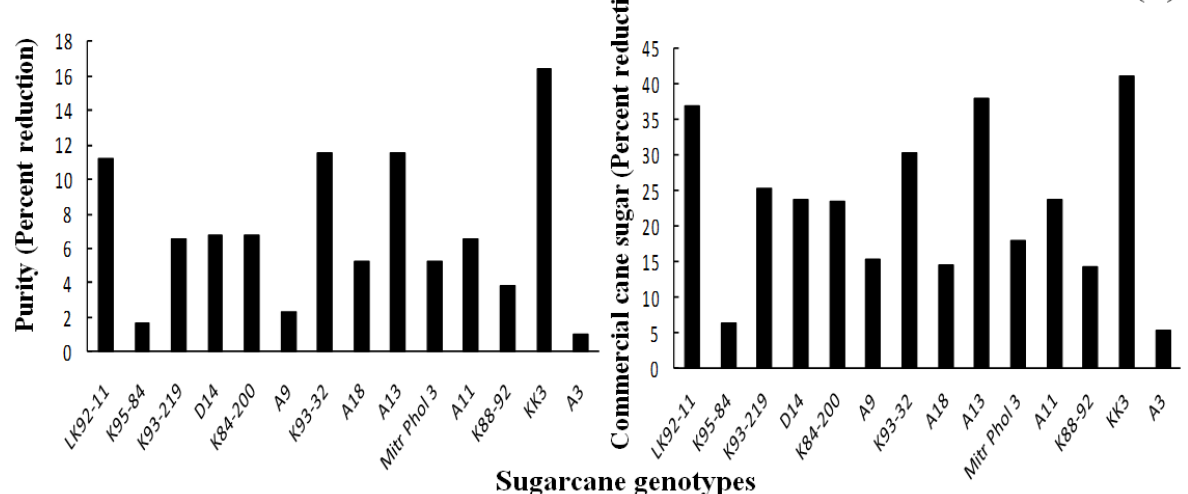

Fig. 3. Percent reduction in brix (A), polarization (B), purity (C), and commercial cane sugar $(\mathrm{D})$ in 14 sugarcane genotypes grown under non-saline (control) and salt-affected soils for 10 months

\section{Rescaled Distance Cluster Combine}

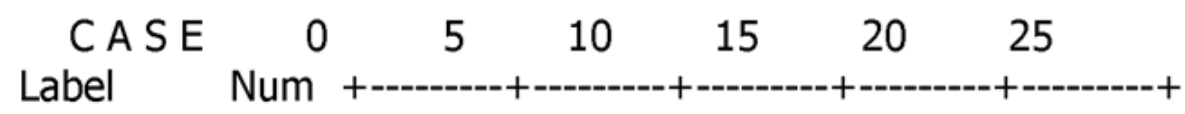

K97-32

A11

LK92-11

A13

D14

A9

K93-219

A18

K84-200

Mitr Phol 3

K95-84

K88-92

A3

KK3

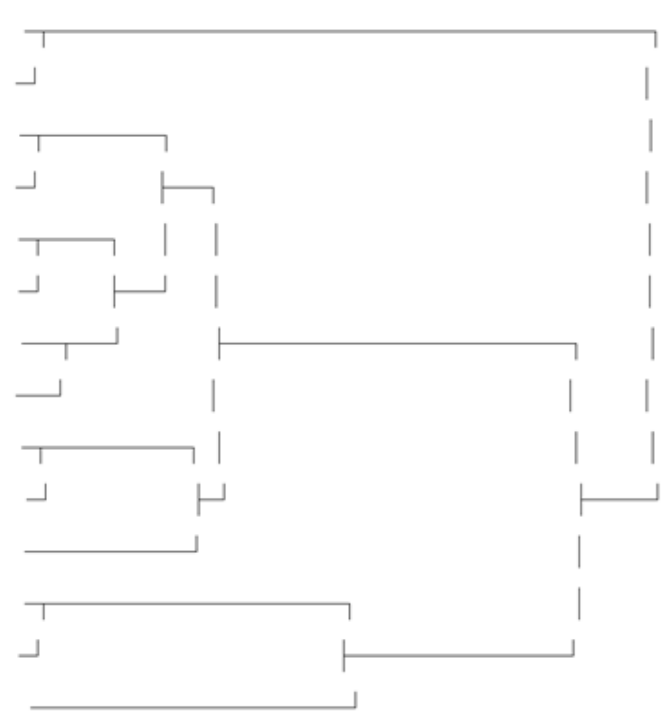

Fig. 4. Ward's dendrogram showing the classification of mutant sugarcane genotypes based on data for photosynthetic abilities, growth performances, yield and sugar quality traits (salt sensitive, 'A11' and 'K97-32', and salt tolerant, 'A3', 'KK3' and 'K88-92') 
plants of sugarcane genotypes was evident. Multivariate analysis of data for all parameters allowed discriminating among the sugarcane cultivars for salt tolerance. Sugarcane cultivars '(A3)AE1-11' and 'KK3' were identified as salt tolerant using the Ward's cluster analysis as was the positive control 'K88-92'.

\section{Acknowledgments}

The authors wish to thank the Mitr Phol Co. Ltd. as a funding source and Dr. Upsorn Pliansinchai, Mitr Phol Co. Ltd. for providing a basic facility of salt affected field.

\section{References}

Akhtar S, Wahid A, Akram M, Rasul E (2001). Effect of $\mathrm{NaCl}$ salinity on yield parameters of some sugarcane genotypes. Int J Agric Biol 3:507-509.

Akhtar S, Wahid A, Rasul E (2003). Emergence, growth and nutrient composition of sugarcane sprouts under $\mathrm{NaCl}$ salinity. Biol Plant 46:113-116.

Cha-um S, Chuencharoen S, Mongkolsiriwatana C, Ashraf M, Kirdmanee C (2012). Screening sugarcane (Saccharum sp.) genotypes for salt tolerance using multivariate cluster analysis. Plant Cell Tis Org Cult 110:23-33.

Cha-um S, Boriboonkaset T, Pichakum A, Kirdmanee C (2009). Multivariate physiological indices for salt tolerant classification in indica rice (Oryza sativa L. spp. indica). Gen Appl Plant Physiol 35:75-87.

Cha-um S, Supaibulwatana K, Kirdmanee C (2007). Glycinebetaine accumulation, physiological characterizations and growth efficiency in salt-tolerant and salt-sensitive lines of indica rice (Oryza sativa L. ssp. indica) in response to salt stress. J Agron Crop Sci 193:157-166.

Cha-um S, Mosaleeyanon K, Kirdmanee C, Supaibulwatana K (2003). A more efficient transplanting system for Thai neem (Azadirachta siamensis Val.) by reducing relative humidity. Sci Asia 29:189-196.

Davenport R, James RA, Zakrisson-Plogander A, Tester M, Munns R (2005). Control of sodium transport in durum wheat. Plant Physiol 137:807-818.

Gandonou CB, Bada F, Gnancadja L, Abrini J, Skali-Senhaji N (2011). Effects of $\mathrm{NaCl}$ on $\mathrm{Na}^{+}, \mathrm{Cl}^{-}$and $\mathrm{K}^{+}$ions accumulation in two sugarcane (Saccharum sp.) cultivars differing in their salt tolerance. Int J Plant Physiol Biochem 3:55-162.

Gomathi R, Thandapani PV (2004). Sugar metabolism and carbon partitioning of sugarcane genotypes under salinity stress condition. Sugar Technol 6:151-158.
Gomathi R, Vasantha S, Thandapani V (2010). Mechanism of osmo regulation in response to salinity stress in sugarcane. Sugar Technol 12:305-311.

Gomathi R, Rakkiyapan P (2011). Comparative lipid peroxidation, leaf membrane themostability, and antioxidant system in four sugarcane genotypes differing in salt tolerance. Int $\mathrm{J}$ Plant Physiol Biochem 3:67-74.

Gomathi R, Thandapani PV (2005). Salt stress in relation to nutrient accumulation and quality of sugarcane genotypes. Sugar Technol 7:39-47.

Lingle SE, Wiegand CL (1997). Soil salinity and sugarcane juice quality. Field Crop Res 54:259-268.

Loggini B, Scartazza A, Brugnoli E, Navari-Izzo F (1999). Antioxidant defense system, pigment composition, and photosynthetic efficiency in two wheat cultivars subjected to drought. Plant Physiol 119:1091-1099.

Maxwell K, Johnson GN (2000). Chlorophyll fluorescence - a practical guide. J Exp Bot 51:659-668.

Meade GP, Chen JCP (1977). Cane Sugar Hand Book. $10^{\text {th }}$ edition, A Wiley Inter Science Publication. John Wiley Sons, New York, 947 p.

Munns R, James RA, Läuchli A (2006). Approaches to increasing the salt tolerance of wheat and other cereals. J Exp Bot 57:1025-1043.

Murashige T, Skoog F (1962). A revised medium for rapid growth and bioassays with tobacco tissue cultures. Physiol Plant 15:473-479.

Plaut Z, Meinzer FC, Federman E (2000). Leaf development, transpiration and ion uptake and distribution in sugarcane cultivars grown under salinity. Plant Soil 218:59-69.

Saxena P, Srivastava RP, Sharma ML (2010). Studies on salinity stress tolerance in sugarcane varieties. Sugar Technol 12:5963.

Tester M, Davenport R (2003). $\mathrm{Na}^{+}$tolerance and $\mathrm{Na}^{+}$transport in higher plants. Ann Bot 91:503-527.

Vasantha S, Venkataramana S, Rao PNG, Gomathi R (2010). Long term salinity effect on growth, photosynthesis and osmotic characteristics in sugarcane. Sugar Technol 12:5-8.

Wiedenfeld B (2008). Effects of irrigation water salinity and electrostatic water treatment for sugarcane production. Agric Water Manage 95:85-88. 